\title{
APRESENTAÇÃO: CRÔNICA DE MACHADO DE ASSIS DE 19 DE MAIO DE 1888
}

\author{
Cilaine Alves Cunha
}

No conjunto da obra de Machado de Assis, produzida a partir de 1880, as narrativas sobre a escravidão - como os contos "Pai contra mãe" e "O caso da vara" - submetem a reflexão sobre a determinação das paixões na conduta humana ao esforço maior de analisar as contradições da hora histórica do país. Estilizando a força cega da ordem escravista a agir na consciência e nas distorções da vida social, o estilo machadiano, em geral marcado por uma ironia fina e galhofeira, conforma, nessas narrativas, um sarcasmo que acentua o tom trágico sobre o cômico.

A crônica de 19 de maio de 1888 faz parte da série "Bons Dias", divulgada na Gazeta de Notícias entre abril desse ano até agosto de 1889. Nela, Machado recorta, como é próprio do gênero, a trivialidade de um acontecimento corriqueiro, como um jantar entre amigos, mas modifica a natureza agradável e amena do relato de circunstância. O texto envolve o evento com uma leitura sobre o tempo imediato da Abolição, entrelaçando as fronteiras da crônica do cotidiano com ficção e reflexão, fundindo, como diz o autor, o sério e o frívolo.

Num dos episódios dessa crônica, a concessão da carta de alforria ocorre uma semana antes de ser decretada a Abolição. Para pintar o ato comemorativo de outorga da carta com traços do absurdo, o autor põe em cena uma primeira pessoa dotada de uma inacreditável consciência escravocrata que se coloca como um abolicionista, elogiando a liberdade na prática da escravidão. No jantar solene, o narrador-personagem exagera e, na hipérbole, deforma o louvor a seu ato de conceder a inevitável liberação de seu escravo. Mas de seu autoelogio emerge também uma espécie de terceira pessoa implícita e crítica que se presentifica, entre outras estratégias, na paródia do discurso do beletrista.

A consciência crítica do autor comparece na configuração do estilo discursivo da primeira pessoa, ou melhor, na seleção e reunião funcional de termos como après coup, post facto, depois do gato morto, perdido por mil, perdido por mil e quinhentos. O efeito cômico dessa esdrúxula combinação de expressões já abala, de início, o declarado altruísmo. Ao pretender haver se antecipado ao ato oficial previamente tido por 
certo, a personagem afirma o fato consumado como iniciativa própria, reassegurando o escravo como uma propriedade de que dispõe, independentemente da decisão governamental. No anúncio de sua deliberação, a mistura de estrangeirismos - concorrendo com a suposta preferência pela expressão vernácula -, metáforas bíblicas e provérbios de extração popular encena a impostação do plurilinguismo, o pedantismo, o falso purista da língua nacional, a pseudoerudição e a hipócrita adesão ao abolicionismo.

O contraponto crítico entre a interpretação do evento pela personagem e pela consciência crítica também se evidencia na estrutura da crônica em duas partes inversamente simétricas, antitéticas e sem solução de síntese. Na metade inicial do texto, a história se desenrola como um monólogo que, em tom de conversa com o leitor, descreve o pomposo jantar composto pelo reduzido público formado por cinco convidados. A cena teatraliza a organização da atividade comemorativa como estratégia de instrumentalização das conquistas trabalhistas em favor do interesse privado de divulgar a imagem do medalhão que se prepara para lançar sua candidatura ao legislativo.

A partir da segunda metade da crônica, no entanto, desaparece a representação da esfera pública representada pelo diminuto grupo de convivas. Nesse momento, o relato da cena privada se desenrola por meio de um falso diálogo entre o futuro deputado e o escravo liberto, tratando dos termos do contrato de trabalho na situação da Abolição. Na conversa, as intervenções de Pancrácio, outra designação irônica, enunciam-se por frases breves, entrecortadas ou suspensivas, o que alude à sua humilde submissão, mas também ao anseio com os dilemas do emprego e ao receio por sua sobrevivência.

Em contrapartida, a falácia e a prolixidade do discurso do patriarca ocupam quase todo o espaço do diálogo, sem deixar lugar ao contradito. O despótico escravocrata naturaliza a miséria salarial, o arbítrio e a violência, aproximando o trabalhador do mundo animal, aludido no galináceo, e o ritmo do aumento de seu salário à lenta deglutição da ave. Naturalizando o agudo conflito social, o patriarca repõe a ideologia da resignação, manifesta desprezo pela condição do trabalhador e se desobriga de sua responsabilidade pela perpetuação da barbárie.

O sistema alegórico da crônica figura aos poucos o diagnóstico sobre a permanência da escravidão no regime de trabalho formal. Machado constata a impossibilidade de emancipar o trabalhador num cenário social de recorrente desrespeito aos direitos essenciais, como às condições mínimas de sobrevivência, à segurança física e de acesso ao sistema educacional, carência esta figurada no dialeto de Pancrácio. Retardatário incapaz de restaurar a justiça, o patriarca mente sobre a formação educacional e profissional de Pancrácio, promovendo uma fraude da Abolição e um estelionato eleitoral. 


\section{Crônica de 19 de maio de 1888}

\section{Machado de Assis}

\section{BONS DIAS!}

Eu pertenço a uma família de profetas après coup, post factum, depois do gato morto, ou como melhor nome tenha em holandês. Por isso digo, e juro se necessário for, que toda a história desta lei de 13 de maio estava por mim prevista, tanto que na segunda-feira, antes mesmo dos debates, tratei de alforriar um molecote que tinha, pessoa de seus dezoito anos, mais ou menos. Alforriá-lo era nada; entendi que, perdido por mil, perdido por mil e quinhentos, e dei um jantar.

Neste jantar, a que meus amigos deram o nome de banquete, em falta de outro melhor, reuni umas cinco pessoas, conquanto as notícias dissessem trinta e três (anos de Cristo), no intuito de lhe dar um aspecto simbólico.

No golpe do meio (coup du milieu, mas eu prefiro falar a minha língua), levantei-me eu com a taça de champanha e declarei que, acompanhando as ideias pregadas por Cristo, há dezoito séculos, restituía a liberdade ao meu escravo Pancrácio; que entendia que a nação inteira devia acompanhar as mesmas ideias e imitar o meu exemplo; finalmente, que a liberdade era um dom de Deus, que os homens não podiam roubar sem pecado.

Pancrácio, que estava à espreita, entrou na sala, como um furacão, e veio abraçar-me os pés. Um dos meus amigos (creio que é ainda meu sobrinho) pegou de outra taça, e pediu à ilustre assembleia que correspondesse ao ato que acabava de publicar, brindando ao primeiro dos cariocas. Ouvi cabisbaixo; fiz outro discurso agradecendo, e entreguei a carta ao molecote. Todos os lenços comovidos apanharam as lágrimas de admiração. Caí na cadeira e não vi mais nada. De noite, recebi muitos cartões. Creio que estão pintando o meu retrato, e suponho que a óleo.

No dia seguinte, chamei o Pancrácio e disse-lhe com rara franqueza:

— Tu és livre, podes ir para onde quiseres. Aqui tens casa amiga, já conhecida e tens mais um ordenado, um ordenado que...

— Oh! meu senhô! fico.

- ... Um ordenado pequeno, mas que há de crescer. Tudo cresce neste mundo; tu cresceste imensamente. Quando nasceste, eras um pirralho deste tamanho; hoje estás mais alto que eu. Deixa ver; olha, és mais alto quatro dedos... 
- Artura não qué dizê nada, não, senhô...

- Pequeno ordenado, repito, uns seis mil-réis; mas é de grão em grão que a galinha enche o seu papo. Tu vales muito mais que uma galinha.

- Justamente. Pois seis mil-réis. No fim de um ano, se andares bem, conta com oito. Oito ou sete.

Pancrácio aceitou tudo; aceitou até um peteleco que lhe dei no dia seguinte, por me não escovar bem as botas; efeitos da liberdade. Mas eu expliquei-Ihe que o peteleco, sendo um impulso natural, não podia anular o direito civil adquirido por um título que lhe dei. Ele continuava livre, eu de mau humor; eram dois estados naturais, quase divinos.

Tudo compreendeu o meu bom Pancrácio; daí para cá, tenho-lhe despedido alguns pontapés, um ou outro puxão de orelhas, e chamo-lhe besta quando Ihe não chamo filho do diabo; coisas todas que ele recebe humildemente, e (Deus me perdoe!) creio que até alegre.

O meu plano está feito; quero ser deputado, e, na circular que mandarei aos meus eleitores, direi que, antes, muito antes de abolição legal, já eu, em casa, na modéstia da família, libertava um escravo, ato que comoveu a toda a gente que dele teve notícia; que esse escravo tendo aprendido a ler, escrever e contar (simples suposição) é então professor de filosofia no Rio das Cobras; que os homens puros, grandes e verdadeiramente políticos, não são os que obedecem à lei, mas os que se antecipam a ela, dizendo ao escravo: és livre, antes que o digam os poderes públicos, sempre retardatários, trôpegos e incapazes de restaurar a justiça na terra, para satisfação do céu.

BOAS NOITES. 